発達期脳に対する麻酔薬の毒性, 最新の知見一基礎から今日の臨床をどうするか一

発達期脳への麻酔薬暴露による中枢神経障害

一これまでの研究と中枢神経障害をどう防ぐか一

湯舟晋也*

[要旨] これまでの研究により, 動物において発達期の麻酔薬暴露が中枢神経毒性をきたし, 成長 後の学習・行動異常を引き起こすことがわかった．これらは主に㗉歯類での報告で, ヒトに当ては まるかどうかは不明である. 近年, 霊長類であるアカゲザルを用いた研究により, 発達期麻酔薬暴 露が踾歯類と同様に毒性をきたすことが報告された. 米国において進行中のヒトでの前向き大規模 臨床試験の結果は, 将来の小児麻酔の方法を大きく変えるかもしれない. これまで, 毒性を軽減す る方法についてさまざまな議論が交わされてきたが, 臨床応用可能な方法は確立されていない. 本 稿では麻酔薬暴露による毒性研究の歴史を解説し, 水素による毒性軽減の可能性について述べる. キーワード: 発達期, 神経毒性, 酸化ストレス, 分子状水素

はじめに

1963 年にWiesel と Hubelが，仔ネコの片眼を一 時的に遮蔽すると，大脳皮質視覚野の神経細胞が遮 蔽した眼に反応しなくなるが，この現象は成長した ネコでは見られないことを報告した ${ }^{1)}$ 。このように， 発達初期の経験や刺激に応じて神経回路を改変しな がら脳機能を発現させていくこの時期のことを臨界 期あるいは感受性期という。臨界期は発達期の一部 であり, 発達期脳は柔軟性に富み, 運動, 感覚, 記 憶, 言語, 思考などの機能の獲得と向上にはこの時 期の経験や学習が極めて重要であることはよく知ら れている。

1999年に Ikonomidou らは, 発達期ラットにおいて NMDA 受容体の遮断が広範な神経細胞死を引き起
こすことを報告し ${ }^{2)} ， ま た 2000$ 年にはエタノールが 同様に広範な神経細胞死をきたすことを報告した ${ }^{3)}$. これらの薬剤はN-methyl-D-aspartate(NMDA)受 容体を遮断し gamma-aminobutyric acid(GABA) 受容体を活性化させるが，われわれが日常的に使う 全身麻酔薬の多くは同様の作用を持つ。2003年に Jevtovic-Todorovic らは，当時全身麻酔薬として使 用頻度の高かった亜酸化窒素，ミダゾラム，イソフ ルランが発達期ラットに中枢神経毒性をきたすこと を報告した ${ }^{4)}$ 。この報告では, 発達期に麻酔薬暴露 されたラットでは，学習や記憶の形成に関与すると いわれる海馬においてシナプスの長期増強が抑制さ れていることを証明し，また発達期に麻酔薬暴露さ れたラットを成獣まで成長させると，モリス水迷路 試験により空間記憶学習能力に異常をきたしている 自衛隊横須賀病院麻酔科 
ことがわかった. 2009 年にはSatomotoらが, 発達 期マウスに吸入全身麻酔薬であるセボフルランを暴 露させると中枢神経に広範な神経細胞死を引き起こ し, 成長後に社会性行動などに異常をきたすことを 報告した ${ }^{5)}$ 。これらの報告は䠛歯類を対象とした研 究の成果であり, 結果がヒトに当てはまるかどうか は議論の余地があるが，近年では霊長類のアカゲザ ルを発達期に麻酔薬暴露させ, 中枢神経毒性が引き 起こされたとの報告もある ${ }^{6)}$.

\section{Iヒトでの前向き臨床試験}

ヒトにおける研究成果は現在のところ限定的であ る。 2 歳までに手術を受けると, それ以降に手術を 受けるよりも行動異常をきたす割合が増加するとす る報告や ${ }^{7)}$ ，2歳までの複数回の麻酔への暴露は認知 機能障害をきたすという報告もあるが8), 研究対象 者の居住地が限られている点や, 研究の性質上対象 を前向きに追跡することの困難さから, 研究成果に 疑問を呈する声も多い. 小児における全身麻酔薬の 使用に関する危機的な問題を明らかにするために， IARS(International Anesthesia Research Society) と FDA (米国食品医薬品局)が共同してプロジェク トを開始している. SmartTots (Strategies for Mitigating Anesthesia-Related NeuroToxicity in Tots) といわれるこのプロジェクトは，ヒトにおいて小児 期に全身麻酔を受ける児を前向きに追跡し，学習や 行動などを評価するものであり現在進行中である. これらのプロジェクトの結果により, 今後, 新しい 知見を得られる可能性がある。

\section{II 麻酔薬暴露による神経障害メカニズム}

発達期に麻酔薬に暴露されることにより引き起こ される中枢神経障害のメカニズムは明らかになって いない. 古くからは, 麻酔薬によるNMDA受容体 の抑制，GABA受容体の興奮が関与しているとい われ2), 全身麻酔薬が神経栄養因子を減少させるた めとする報告や ${ }^{9)}$ ，イノシトール 3 リン酸受容体の
活性化を介した結果であるとする報告もある ${ }^{10)}$ 。近 年では活性酸素種 (reactive oxygen species：ROS) が関係するミトコンドリア関連経路によりアポトー シスをきたすとする報告や ${ }^{11}$ ，麻酔薬暴露によりミ トコンドリアの形態変化やROSの up regulationが 起こるとする報告 ${ }^{12)}$ のうう，酸化ストレスに注目 した報告が多い。

Bcl-2 というタンパクは，ミトコンドリアの外壁 に存在し抗アポトーシス蛋白と呼ばれ，シトクロム cの放出を抑制している。これに対してプロアポト ーシス蛋白と呼ばれるBax は細胞質に存在するが, ミトコンドリアに移動してシトクロム $\mathrm{c}$ の放出を促 進する。これらがバランスをとりつつアポトーシス を制御しているが，全身麻酔薬の暴露により Bax が増加し Bcl-2が減少することでミトコンドリアが 障害を受け，シトクロム $\mathrm{c}$ の放出が促進され神経細 胞死につながると考えられている ${ }^{11}$.

\section{III＼cjkstart麻酔薬からの中枢神経保護}

麻酔薬による中枢神経毒性を軽減するためのさま ざまな方法が研究されている。リチウムの腹腔内投 与がマウスにおいて麻酔薬によるアポトーシスを軽 減させたというものや ${ }^{13)}$, メラトニンやカルニチン の投与が $\mathrm{Bcl}-2$ を増加させシトクロム $\mathrm{c}$ の放出を抑 制させることで抗アポトーシス効果を発揮するとい う報告がある ${ }^{14)}$ 。また鎮静薬として近年使用頻度の 高いデクスメデトミジン投与がアポトーシスを抑制 するとする報告もある ${ }^{15)}$ ，しかし確実な中枢神経保 護作用を期待でき，かつ臨床応用に耐える方法の確 立に至っていないのが現状である。

われわれは，麻酔薬による中枢神経毒性のメカニ ズムに酸化ストレスが関与している可能性から, ROSのスカベンジャーとしての分子状水素に注目 した，ROSは，酸素分子がより反応性の高い化合 物に変化したものの総称であるが，発達期脳には， スーパーオキシド, $\mathrm{H}_{2} \mathrm{O}_{2}, \mathrm{~N}_{2} \mathrm{O}$ などの $\mathrm{ROS}$ は少量 必要であることがわかっている.ROSの中でも, 
ヒドロキシラジカルはその beneficial roleが報告さ れておらず, 除去できるシステムが哺乳類にはない. しかし分子状水素は，ROSの中でも場合によって は生体にとって必要なスーパーオキシド, $\mathrm{H}_{2} \mathrm{O}_{2}$ な どは除去せず，最も毒性の高いヒドロキシラジカル のみを除去する ${ }^{16)}$ 。また分子状水素は非常に安価で あり，血液脳関門を通過し中枢神経に到達でき，無 味無臭であり気道刺激がない。 さらに代謝産物が蓄 積せずに副作用の報告がなく, carrier gasに混ぜ ることで使用可能であるという臨床応用の可能性を 秘めている。 Ohsawa らは，ラット中枢神経におい て虚血再灌流により酸化ストレスを引き起こし，分 子状水素がこの障害に対して保護効果があることを 証明した ${ }^{16)}$ 。また Yonamine らは全身麻酔薬である セボフルランによる中枢神経毒性を, 分子状水素を carrier gas として投与することで軽減すると報告し た ${ }^{17)}$.

\section{IV デスフルランによる中枢神経毒性に対する 分子状水素の神経保護効果}

近年使用頻度が高い全身麻酔薬であるデスフルラ ンを発達期マウスに暴露させると, 他の吸入麻酔薬 よりも広範な神経細胞死をきたすことが報告されて いるが18)，われわれは分子状水素がデスフルランに よる中枢神経毒性に対して保護効果があるかどうか を評価検討した。発達期とされる日齢 6 日目のマウ スを, carrier gasに分子状水素を混合し, デスフ ルランに暴露させて western blot法および免疫染色 により対照群と比較した。Western blot法によりア ポトーシスの指標となる PARP (poly ADP-ribose polymerase)を解析したところ，デスフルラン投与 群で有意に上昇したアポトーシスが分子状水素投与 により軽減していることがわかった。また caspase-3 による免疫染色でも同様の結果を得た。これらの結 果より, 分子状水素がセボフルランだけでなく, デ スフルランによる中枢神経毒性に対しても保護効果 がある可能性があることがわかった。

\section{まとめ}

麻酔薬による発達期中枢神経毒性は，哺乳類を含 む動物による研究では実証されているが，ヒトに当 てはまるかどうかはいまだに議論の最中であり，実 際の臨床における麻酔方法の選択や，待機的手術を 受ける時期の選択に影響を与えるには至っていな い.中枢神経毒性を発揮するメカニズムに関しては, 関与する経路が少しずつ明らかにされているのみ で，その関連する流れがすべて解明できているわけ ではない。酸化ストレスによるミトコンドリア障害 に対して，ROSスカベンジャーとしての分子状水 素の有効性が明らかになってきたが，臨床応用でき る中枢神経保護剤として期待できるものの, さらな る研究が必要である。

\section{参考文献}

1) Wiesel TN, Hubel DH : Single-cell responses in striate cortex of kittens deprived of vision in one eye. J Neurophysiol $26: 1003-1017,1963$

2) Ikonomidou C, Bosch F, Miksa M, et al. : Blockade of NMDA receptors and apoptotic neurodegeneration in the developing brain. Science $283: 70-74,1999$

3) Ikonomidou C, Bittigau P, Ishimaru MJ, et al. : Ethanol-induced apoptotic neurodegeneration and fetal alcohol syndrome. Science $287:$ 1056-1060, 2000

4) Jevtovic-Todorovic V, Hartman RE, Izumi $Y$, et al. : Early exposure to common anesthetic agents causes widespread neurodegeneration in the developing rat brain and persistent learning deficits. J Neurosci 23 : 876-882, 2003

5) Satomoto M, Satoh Y, Terui K, et al. : Neonatal exposure to sevoflurane induces abnormal social behaviors and deficits in fear conditioning in mice. Anesthesiology $110: 628-637,2009$

6) Brambrink AM, Back SA, Riddle A, et al. : Isofluraneinduced apoptosis of oligodendrocytes in the neonatal primate brain. Ann Neurol $72:$ 525-535, 2012

7) Kalkman CJ, Peelen L, Moons KG, et al. : Behavior and development in children and age at the time of first anesthetic exposure. Anesthesiology $110: 805-812$, 2009

8) Flick RP, Katusic SK, Colligan RC, et al. : Cognitive 
and behavioral outcomes after early exposure to anesthesia and surgery. Pediatrics 128 : e1053-e1061, 2011

9) Lu LX, Yon JH, Carter LB, et al. : General anesthesia activates BDNF-dependent neuroapoptosis in the developing rat brain. Apoptosis 11 : 1603-1615, 2006

10) Wei H, Liang G, Yang H, et al. : The common inhalational anesthetic isoflurane induces apoptosis via activation of inositol 1,4,5-trisphosphate receptors. Anesthesiology $108: 251-260,2008$

11) Zhang Y, Dong Y, Wu X, et al. : The mitochondrial pathway of anesthetic isoflurane-induced apoptosis. J Biol Chem 285 : 4025-4037, 2010

12) Boscolo A, Milanovic D, Starr JA, et al. : Early exposure to general anesthesia disturbs mitochondrial fission and fusion in the developing rat brain. Anesthesiology 118 : 1086-1097, 2013

13) Straiko MM, Young C, Cattano D, et al. : Lithium protects against anesthesia-induced developmental neuroapoptosis. Anesthesiology 110 : 862-868, 2009

14) Zou X, Sadovova N, Patterson TA, et al. : The effects of $\mathrm{L}$-carnitine on the combination of, inhalation anes- thetic-induced developmental, neuronal apoptosis in the rat frontal cortex. Neuroscience 151: 1053-1065, 2008

15) Sanders RD, Sun P, Patel S, et al. : Dexmedetomidine provides cortical neuroprotection : impact on anaesthetic-induced neuroapoptosis in the rat developing brain. Acta Anaesthesiol Scand 54 : 710-716, 2010

16) Ohsawa I, Ishikawa M, Takahashi $K$, et al. : Hydrogen acts as a therapeutic antioxidant by selectively reducing cytotoxic oxygen radicals. Nat Med $13: 688-694$, 2007

17) Yonamine R, Satoh Y, Kodama M, et al. : Coadministration of hydrogen gas as part of the carrier gas mixture suppresses neuronal apoptosis and subsequent behavioral deficits caused by neonatal exposure to sevoflurane in mice. Anesthesiology 118 : 105-113, 2013

18) Kodama M, Satoh Y, Otsubo Y, et al. : Neonatal desflurane exposure induces more robust neuroapoptosis than do isoflurane and sevoflurane and impairs working memory. Anesthesiology 115 : 979-991, 2011

\title{
Anesthesia-related Neurotoxicity in the Developing Brain : How It Can Be Reduced
}

\author{
Shinya YUFUNE \\ Department of Anesthesiology, Japan Self Defense Forces Hospital Yokosuka
}

In animal models, neuronal apoptosis was induced by several anesthetics in the developing brain and this interruption could cause deficits in brain function in adulthood including social deficits. Recent research has revealed that exposure of the infant rhesus macaque brain to isoflurane causes widespread neuroapoptosis. However, inadequate human data exist to affirm the possibility that similar effects occur in human children. Previous studies showed many potential mechanisms of neuroapoptosis in immature animal brains but there are no promising therapeutic strategies to mitigate neurotoxicity. The purpose of this article is to discuss anesthesia-related neurotoxicity and the possible therapeutic applicability of molecular hydrogen as an antioxidant.

Key Words : Developing brain, Neuroapoptosis, Oxidative stress, Molecular hydrogen

\section{The Journal of Japan Society for Clinical Anesthesia Vol.36 No.2, 2016}

